\section{ANTHROPOMETRIC VALUES OF SPANISH BEACH VOLLEYBALL PLAYERS IN RELATION TO SPORTS PERFORMANCE LEVEL}

\author{
VALORES ANTROPOMÉTRICOS DE JOGADORES ESPANHÓIS DE VÔLEI DE PRAIA EM RELAÇÃO AO NÍVEL \\ DERENDIMENTO ESPORTIVO

\section{VALORES ANTROPOMÉTRICOS DE JUGADORES ESPAÑOLES DEVÓLEIBOL DEPLAYA CON RELACIÓNAL NIVEL DERENDIMIENTO DEPORTIVO}

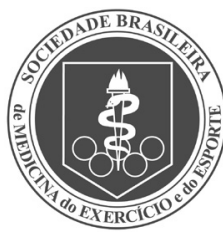

Original Article Artigo Original Artículo Original

\begin{abstract}
Miriam Esther Quiroga Escudero'(1) (Physical Education Professional) Antonio Palomino Martín' (iD) (Physical Education Professional) Samuel Sarmiento Montesdeoca ${ }^{1}$ (ID (Physical Education Professional) David Rodríguez Ruiz' (ID) (Physical Education Professional) Juan Manuel García Manso' (DD (Physical Education Professional)

University of Las Palmas de Gran Canaria, Department of Physical Education, Las Palmas de Gran Canaria, Canary Islands, Spain.
\end{abstract}

\section{Correspondence:}

Miriam Esther Quiroga Escudero. Edificio de Educación Física, Campus Universitario de Tafira, $s / n$ Las Palmas de Gran Canaria, Spain. 35017.miriam.quiroga@ulpgc.es

\begin{abstract}
Introduction: Since its debut at the 1996 Atlanta Olympics, beach volleyball has grown on the international sports scene. An extensive collection of data from several countries and levels of competition will provide a database that can be used to characterize beach volleyball players and define references for training stages. Objective: The purpose of this study was to describe and compare the anthropometric profiles of Spanish male and female beach volleyball players at different levels of competition in relation to sports performance. Methods: The sample comprised 150 players participating in the 2011 Spanish Beach Volleyball Championships (Under 19, Under 21, and Senior categories). Using the ranking provided by the Royal Spanish Volleyball Federation, the subjects were distributed by performance level (level 1: players ranked first to fourth; level 2: players ranked fifth to ninth; and level 3: players ranked tenth to seventeenth). The study comprised a group of male players, with 18 level 1 (M1), 39 level 2 (M2), and 22 level 3 players (M3), and a group of female players, with 18 level 1 (F1), 41 level 2 (F2), and 12 level 3 players (F3). Results: The top level male sample (M1) had a significantly lower average age (19.33 years) than the men's international elite players (30 years). The top Spanish players of both genders had much lower values for height and body weight than the international elite players. Conclusions: Height and fat component are responsible for the differences between top and lower level beach volleyball players, for both men and women. Moreover, as the level of performance increases, players are taller and have a lower fat component. In view of the data observed in this study, the talent selection process in Spanish beach volleyball should aim to select taller individuals than at present. Level of evidence III; Therapeutic studies-Investigating the results of treatment.
\end{abstract}

Keywords: Body composition; Sports; Classification; Trends.

\section{RESUMO}

Introdução: Desde sua estréia nas Olimpíadas de Atlanta em 1996, o vôlei de praia cresceu internacionalmente. Uma abrangente coleta de dados de diferentes países e niveis de competição fornecerá um banco de dados que pode ser utilizado para caracaterizar os jogadores de volêi de praia e definir referências para as etapas do treinamento. Objetivo: 0 propósito desse estudo consiste em descrever e comparar os perfis antropométricos de jogadores ejogadoras espanhóis de vôlei de praia, de diferentes níveis de competição, em relação ao rendimento esportivo. Métodos: A amostra compreendeu 150 jogadores participantes do Campeonato Espanhol de Vôlei de Praia de 2011 (categorias Sub-19, Sub-21 e Sênior). Ao usar o ranking fornecido pela Real Federação Espanhola de Voleibol, os jogadores foram distribuídos através de niveis de rendimento (nivvel 1: jogadores entre o primeiro e quarto colocado; nivel 2: entre o quinto e nono colocado e nível 3: a partir do décimo até o décimo-sétimo colocado). O estudo incluiu um grupo de 18 jogadores do nível 1 (M1), 39 do nível 2 (M2) e 22 do nível 3 (M3) e 18 jogadoras do nível 1 feminino (F1), 41 do nível 2 (F2) e 12 do nível 3 (F3). Resultados: A amostra masculina de alto nível (M1) apresentou uma idade média significativamente menor (19,33 anos) do que os jogadores da elite internacional (30 anos). A estatura e o peso corporal dos jogadores espanhóis de nível mais alto, em ambos os sexos, apresentaram valores inferiores aos apresentados pelos jogadores da elite internacional. Conclusão: A altura e o componente de gordura são responsáveis pelas diferenças entre os jogadores de vôlei de praia de alto nivel e nivel inferior, tanto para homens quanto para mulheres. Além disso, quanto mais alto o nível de rendimento, maior a estatura e menor o componente de gordura. Considerando-se os dados observados no estudo, o processo de seleção de talentos no vôlei de praia espanhol deve priorizar a seleção de indivíduos mais altos do que atualmente. Nível de evidência Ill; Estudos terapêuticos-Investigação dos resultados do tratamento.

Descritores: Composição corporal; Esportes; Classificação; Tendências.

\section{RESUMEN}

Introducción: Desde su estreno en las Olimpíadas de Atlanta en 1996, el Vóleibol de Playa creció internacionalmente. Una amplia colecta de datos de diferentes países y niveles de competición proveerá un banco de datos que puede ser utilizado para caracterizar a los jugadores de vóleibol de playa y definir referencias para las etapas del entrenamiento. 
Objetivo: El propósito deesteestudio consiste en describiry comparar los perfiles antropométricos dejugadores yjugadoras españoles de Vóleibol de Playa, de diferentes niveles de competición, con relación al rendimiento deportivo. Métodos: La muestra comprendió a 150 jugadores participantes del Campeonato Español de Vóleibol de Playa de 2011 (categorías Sub-19, Sub-21 y Sénior). Al usar el ranking suministrado por la Real Federación Española de Vóleibol, los jugadores fueron distribuidos a través de niveles de rendimiento (nivel 1:jugadores entre el primero y el cuarto colocado; nivel 2: entre el quinto y el noveno colocado; y nivel 3: a partir del décimo hasta el décimo-séptimo colocado). Elestudio incluyó a un grupo de 18 jugadores de nivel 1 (M1), 39 del nivel 2 (M2) y 22 del nivel 3 (M3) y 18jugadoras del nivel 1 femenino (F1), 41 del nivel 2 (F2), y 12 del nivel 3 (F3). Resultados: La muestra masculina de mayor nivel (M1) presentó una edad promedio significativamente menor (19,33 años) que los jugadores de la élite internacional (30 años). La estatura y el peso corporal de los jugadores españoles de nivel más alto, en ambos sexos, presentaron valores inferiores a los presentados por los jugadores de la élite internacional. Conclusión: La altura y el componente de grasa son responsables por las diferencias entre los jugadores de vóleibol de playa de alto nivel y nivel inferior, tanto para hombres como para mujeres. Además, cuanto más alto el nivel de rendimiento, mayor la estatura y menor el componente de grasa. Considerándose los datos observados en el estudio, el proceso de selección de talentos en el Vóleibol de Playa español debe priorizar la selección de individuos más altos que los que hay actualmente. Nivel de evidencia III; Estudios terapéuticos-Investigación de los resultados del tratamiento.

Descriptores: Composición corporal; Deportes; Clasificación, Tendencias.

\section{INTRODUCTION}

Since its debut at the 1996 Atlanta Olympics, beach volleyball has grown on the international sports scene to the point that it was one of the star events of the latest Olympics. ${ }^{1}$ As a result, the number of events and participants in official competitions around the world in recent years has increased, leading in turn to several studies designed to determine some of the characteristics of elite beach volleyball players. ${ }^{2-7}$ Investigations have mainly focused on defining the anthropometric characteristics of top performing players. Their findings have made it possible to identify a model on which to base the talent selection process. ${ }^{8}$ Based on elite players, the model indicates that selection criteria should be for a height of around $194 \mathrm{~cm}$ and a body weight of $88.5 \mathrm{~kg}$ for male players and $178.8 \mathrm{~cm}$ and $67 \mathrm{~kg}$ for female players. ${ }^{4-7,9-11}$ However, we have found no studies on anthropometric characteristics at different stages of beach volleyball training to show whether morphological and constitutional factors affect performance level during the formative stages of a player's life. A more extensive collection of data on beach volleyball players from several countries and competition levels will provide a database to characterise beach volleyball players and make it possible to define specific points of reference for training stages. ${ }^{5}$

The silver medal won in the men's beach volleyball at the 2004 Olympic Games in Athens was Spain's highest achievement in this sport at any Olympics. In order to discover the generational potential in terms of anthropometric values, the objective of this study was to describe and compare the anthropometric profile of Spanish beach volleyball players at different levels of competition, in both the men's and women's categories, in relation to the sports performance level obtained at the most important event of the Spanish beach volleyball calendar.

\section{MATERIALS AND METHODS}

The study sample comprised 150 players participating in the Spanish Beach Volleyball Championships, held in Las Palmas de Gran Canaria in July 2011, at Under 19, Under 21 and Senior level, in both the men's and women's category.

Subjects were assessed by gender and distributed by performance, resulting in 18 male players at level 1 (M1), 39 at level 2 (M2) and 22 at level 3 (M3). The female subjects comprised 18 players at level $1(F 1), 41$ at level 2 (F2) and 12 at level 3 (F3). (Table 1)

The performance groups were formed using the ranking provided by the Royal Spanish Volleyball Federation for each category (Under
Table 1. General characteristics of subjects by ranking and gender.

\begin{tabular}{|c|c|c|c|c|c|c|}
\hline & \multicolumn{3}{|c|}{$\begin{array}{c}\text { Male } \\
(n=79)\end{array}$} & \multicolumn{3}{|c|}{$\begin{array}{c}\text { Female } \\
(\mathrm{n}=71)\end{array}$} \\
\hline & $\begin{array}{c}M 1 \\
(n=18)\end{array}$ & $\begin{array}{c}M 2 \\
(n=39)\end{array}$ & $\begin{array}{c}M 3 \\
(n=22) \\
\end{array}$ & $\begin{array}{c}F 1 \\
(n=18)\end{array}$ & $\begin{array}{c}F 2 \\
(n=41)\end{array}$ & $\begin{array}{c}F 3 \\
(n=12)\end{array}$ \\
\hline $\begin{array}{c}\text { Age } \\
\text { (years) }\end{array}$ & $\begin{array}{r}19.33^{\mathrm{a}} \\
( \pm 4.86) \\
\end{array}$ & $\begin{array}{r}21.43 \\
( \pm 5.33) \\
\end{array}$ & $\begin{array}{c}26.36 \\
( \pm 8.38) \\
\end{array}$ & $\begin{array}{c}19.44 \\
( \pm 5.03) \\
\end{array}$ & $\begin{array}{c}19.95 \\
( \pm 5.26) \\
\end{array}$ & $\begin{array}{r}17.00 \\
( \pm 1.53) \\
\end{array}$ \\
\hline $\begin{array}{l}\text { Height } \\
(\mathrm{cm})\end{array}$ & $\begin{array}{l}187.05^{b} \\
( \pm 6.18) \\
\end{array}$ & $\begin{array}{r}184.66 \\
( \pm 7.55) \\
\end{array}$ & $\begin{array}{r}183.40 \\
( \pm 6.61) \\
\end{array}$ & $\begin{array}{r}173.72 \\
( \pm 4.81) \\
\end{array}$ & $\begin{array}{r}172.36 \\
( \pm 5.59) \\
\end{array}$ & $\begin{array}{r}168.75 \\
( \pm 10.14) \\
\end{array}$ \\
\hline $\begin{array}{l}\text { BW } \\
(\mathrm{kg})\end{array}$ & $\begin{array}{c}76.43 \\
( \pm 8.63)\end{array}$ & $\begin{array}{c}78.89 \\
( \pm 10.26)\end{array}$ & $\begin{array}{c}79.00 \\
( \pm 9.43)\end{array}$ & $\begin{array}{c}64.99 \\
( \pm 4.96)\end{array}$ & $\begin{array}{c}64.88 \\
( \pm 7.89)\end{array}$ & $\begin{array}{c}65.84 \\
( \pm 12.26)\end{array}$ \\
\hline
\end{tabular}

19, Under 21 and Senior). Level 1 was defined as players ranked first to fourth, level 2 as those ranked fifth to ninth and level 3 as players ranked tenth to seventeenth. These groups were established globally in the three categories, divided only by gender. All subjects were informed of the nature of the study and its intended uses. They all gave written consent, following the ethical principles of the Declaration of Helsinki on research involving human subjects (adopted by the $18^{\text {th }}$ Assembly of the World Medical Association, held in Helsinki in 1964, and amended by the $59^{\text {th }}$ General Assembly, held in Seoul in 2008).

Measuring equipment comprised a Vernier Calliper (Holtain Ltd, Crymych, United Kingdom) with a triangular fixed jaw at the head and a second movable jaw, a measuring range of 63 to $213 \mathrm{~cm}$ and a measuring error of $\pm 0.1 \mathrm{~mm}$, and a Detecto balance (Lafayette Instruments Company, Lafayette, Indiana, USA) with a measuring interval of 0 to $150 \mathrm{~kg}$ and accuracy to $200 \mathrm{~g}$. Equipment was regularly calibrated and zero adjustments were made before each measurement. Skinfolds were measured with a Holtain Skinfold Calliper (Holtain Ltd, Dyfed, UK) ${ }^{12}$ with a measuring range of 0 to $48 \mathrm{~mm}, 0.2 \mathrm{~mm}$ dial graduation and $10 \mathrm{~g} / \mathrm{mm}^{2}$ constant pressure. The height of each subject was measured with a Holtain stadiometer (Holtain Ltd, Dyfed, UK), accurate to $1 \mathrm{~mm}$. Girth measurements were taken with a flexible metal measuring tape (Holtain Ltd., Dyfed, UK) with a scale of $0.1 \mathrm{~cm}$.

Measurements were taken for each subject for weight and height; skinfolds of the triceps, subscapularis, suprailiac, abdominals and anterior thigh and lower leg; arm girth (tensed and relaxed) and waist, thigh and lower leg girth; and the biepycondilar diameters of the humerus, femur and biestiloid. Values were also determined for weight in fat and muscle and bone weight; addipose, muscle and bone tissue percentage; and somatotype calculation. The description of anatomical landmarks, body mass, girths, diameters and skinfolds, and the methodology used for 
data collection, correspond to the work by Lohman et al. ${ }^{13}$ Body mass index (BMI) was calculated using the Quetelet index. ${ }^{14}$ Somatotype was assessed through the methodology described by Heath-Carter. ${ }^{15}$ The body composition study was based on the proposal presented by De Rose \& Guimaraes ${ }^{16}$ using the Matiegka equation ${ }^{17}$ and fat percentage was determined using the equation developed by Carter. ${ }^{18}$ Following the recommendations and methodologies of various authors, ${ }^{9-21}$ measurements were taken on players' dominant side.

\section{Statistical analysis}

SPSS for Windows package version 19.0 (SPSS, Inc., Chicago, IL) was used for statistical analysis of the data obtained from the study sample. Basic descriptive statistics were performed on the description of the study variables.

A normality test (Shapiro-Wilk) was applied to each series of data. Depending on each case, comparative statistics to quantify and assess changes between the study variables by category were performed using the paired samples t-test for independent samples and the Mann-Whitney $U$ test for independent samples. The statistical calculations were made using a significance level of $p \leq 0.05$.

\section{RESULTS}

Table 1 shows the mean and standard deviation for the age and basic anthropometric data - height and body weight (BW) - by ranking and gender.

Table 2 shows the body composition data (muscle and fat tissue, in weight and percentage) by ranking and gender.

Body shape and composition of the sample, estimated from the somatotype and its three components (endomorphic, mesomorphic and ectomorphic), organised by ranking and gender, are described in Table 3.

Figure 1 shows the box plots for muscle percentage, fat percentage and sum of skinfolds by ranking and gender.

Table 2. Description of body composition values by ranking and gender.

\begin{tabular}{|c|c|c|c|c|c|c|}
\hline & \multicolumn{3}{|c|}{$\begin{array}{c}\text { Male } \\
(n=79)\end{array}$} & \multicolumn{3}{|c|}{$\begin{array}{c}\text { Female } \\
(n=71)\end{array}$} \\
\hline & $\begin{array}{c}\text { M1 } \\
(n=18)\end{array}$ & $\begin{array}{c}M 2 \\
(n=39)\end{array}$ & $\begin{array}{c}M 3 \\
(n=22)\end{array}$ & $\begin{array}{c}F 1 \\
(n=18)\end{array}$ & $\begin{array}{c}F 2 \\
(n=41)\end{array}$ & $\begin{array}{c}F 3 \\
(n=12)\end{array}$ \\
\hline $\begin{array}{c}\text { Muscle } \\
\text { weight }^{1}(\mathrm{~kg})\end{array}$ & $\begin{array}{c}38.12 \\
( \pm 4.36)\end{array}$ & $\begin{array}{c}39.32 \\
( \pm 4.64)\end{array}$ & $\begin{array}{r}39.07 \\
( \pm 4.42) \\
\end{array}$ & $\begin{array}{c}30.11 \\
( \pm 2.10)\end{array}$ & $\begin{array}{c}29.32 \\
( \pm 3.03)\end{array}$ & $\begin{array}{r}29.20 \\
( \pm 5.39)\end{array}$ \\
\hline $\begin{array}{c}\text { Muscle } \\
\text { Percentage }\end{array}$ & $\begin{array}{c}49.92 \\
( \pm 2.10)\end{array}$ & $\begin{array}{c}49.94 \\
( \pm 1.71) \\
\end{array}$ & $\begin{array}{c}49.53 \\
( \pm 1.83) \\
\end{array}$ & $\begin{array}{c}46.39 \\
( \pm 2.24)\end{array}$ & $\begin{array}{c}45.33 \\
( \pm 2.45)\end{array}$ & $\begin{array}{c}44.49 \\
( \pm 3.06) \\
\end{array}$ \\
\hline $\begin{array}{l}\text { Weight in } \\
\text { fat }(\mathrm{kg})\end{array}$ & $\begin{array}{c}6.50^{a} \\
( \pm 1.75)\end{array}$ & $\begin{array}{c}7.59 \\
( \pm 3.04)\end{array}$ & $\begin{array}{c}8.21 \\
( \pm 2.17)\end{array}$ & $\begin{array}{c}11.22 \\
( \pm 2.04)\end{array}$ & $\begin{array}{c}11.91 \\
( \pm 3.18)\end{array}$ & $\begin{array}{c}13.00 \\
( \pm 3.70)\end{array}$ \\
\hline Fat percentage $^{2}$ & $\begin{array}{c}8.40^{\mathrm{a}} \\
( \pm 1.53)\end{array}$ & $\begin{array}{c}9.41^{b} \\
( \pm 2.55)\end{array}$ & $\begin{array}{c}10.27 \\
( \pm 1.83)\end{array}$ & $\begin{array}{l}17.21^{b} \\
( \pm 2.38)\end{array}$ & $\begin{array}{c}18.14 \\
( \pm 3.00)\end{array}$ & $\begin{array}{c}19.50 \\
( \pm 2.89)\end{array}$ \\
\hline $\begin{array}{c}\sum 6 \text { Skinfolds } \\
(\mathrm{mm})\end{array}$ & $\begin{array}{c}55.37^{a} \\
( \pm 14.62)\end{array}$ & $\begin{array}{c}65.77^{b} \\
( \pm 25.00)\end{array}$ & $\begin{array}{c}73.16 \\
( \pm 17.48)\end{array}$ & $\begin{array}{c}88.10^{b} \\
( \pm 15.38)\end{array}$ & $\begin{array}{c}94.11 \\
( \pm 19.40)\end{array}$ & $\begin{array}{c}102.88 \\
( \pm 18.70)\end{array}$ \\
\hline
\end{tabular}

${ }^{1}$ Equation for calculating Muscle Weight. ${ }^{172}$ Equation for calculating Fat Percentage. ${ }^{18(a)} p \leq 0.01$ (M1 vs. M3); ${ }^{(b)}$ $\mathrm{p} \leq 0.05$ (M2 vs. M3; F1 vs. F3).

Table 3. Description of somatotype values (endomorphy, mesomorphy and ectomorphy) by ranking and gender.

\begin{tabular}{|c|c|c|c|c|c|c|}
\hline & & $\begin{array}{c}\text { Male } \\
(n=79)\end{array}$ & & \multicolumn{3}{|c|}{$\begin{array}{c}\text { Female } \\
(n=71)\end{array}$} \\
\hline & $\begin{array}{c}M 1 \\
(n=18)\end{array}$ & $\begin{array}{c}M 2 \\
(n=39)\end{array}$ & $\begin{array}{c}M 3 \\
(n=22)\end{array}$ & $\begin{array}{c}F 1 \\
(n=18)\end{array}$ & $\begin{array}{c}F 2 \\
(n=41)\end{array}$ & $\begin{array}{c}\text { F3 } \\
(n=12)\end{array}$ \\
\hline Endomorphy & $\begin{array}{l}2.16 \mathrm{ab} \\
( \pm 0.51)\end{array}$ & $\begin{array}{c}2.72 \\
( \pm 1.07) \\
\end{array}$ & $\begin{array}{c}2.92 \\
( \pm 0.72) \\
\end{array}$ & $\begin{array}{c}3.75^{a} \\
( \pm 0.70) \\
\end{array}$ & $\begin{array}{c}3.98 \text { a } \\
( \pm 0.91)\end{array}$ & $\begin{array}{c}4.62 \\
( \pm 0.93) \\
\end{array}$ \\
\hline Mesomorphy & $\begin{array}{c}3.49 \\
( \pm 0.74) \\
\end{array}$ & $\begin{array}{c}3.91 \\
( \pm 1.26) \\
\end{array}$ & $\begin{array}{c}3.94 \\
( \pm 1.10) \\
\end{array}$ & $\begin{array}{c}2.58^{b} \\
( \pm 0.88)\end{array}$ & $\begin{array}{c}2.83 \\
( \pm 1.04) \\
\end{array}$ & $\begin{array}{c}3.25 \\
( \pm 1.01) \\
\end{array}$ \\
\hline Ectomorphy & $\begin{array}{l}3.78 \text { ab } \\
( \pm 0.86)\end{array}$ & $\begin{array}{c}3.10 \\
( \pm 1.30)\end{array}$ & $\begin{array}{c}2.81 \\
( \pm 0.91)\end{array}$ & $\begin{array}{c}3.12^{\mathrm{a}} \\
( \pm 0.81)\end{array}$ & $\begin{array}{c}2.94^{\mathrm{b}} \\
( \pm 1.07)\end{array}$ & $\begin{array}{c}2.17 \\
( \pm 1.00)\end{array}$ \\
\hline
\end{tabular}

(a) $p \leq 0.01$ (M1 vs. M3; F1 vs. F3; F2 vs. F3); ${ }^{(b)} p \leq 0.05$ (M1 vs. M2; F1 vs. F3; F2 vs. F3)

\section{DISCUSSION}

Surprisingly, the age of male Spanish beach volleyball players decreased the higher their ranking was; i.e. the top players (M1) had a lower average age (19.33 years) than players at the other levels (M2 and M3), with statistically significant differences $(p=0.01)$ between the highest (M1) and lowest (M3) performing players. Female players did not have the same distribution: the groups with a higher average age (19.44 and 19.95 years) were ranked higher ( $F 1$ and $F 2$ ).

When we compared our group of top male players (M1) with the 625 players classified at the World Tour and the Olympic Games for the period 2000 to 2006,4 the values of our group were significantly lower (19.33 years) than the average of 30 years for men's international elite players. The same occurred in the sample of female players: the top 617 players had an average age of 28 years, in comparison with the average of 19.44 years of the Spanish players. This was also seen in a study of 16 elite male Brazilian players in the 2009 Brazilian series, who had an average age of 28 years. ${ }^{5}$ When we compared the 2006 Brazilian men's beach volleyball series, whose sample is organised by ranking, ${ }^{3}$ a cross reference of their best players with our sample (M1) showed the same differences (31 years versus 19.33 years in our $M 1$ group), whereas in the lowest ranking Brazilian group, these differences decreased (27.9 years versus 26.36 years in our $M 3$ group).

The characteristics of play make height a determining morphological parameter in beach volleyball. The top male and female players ( $\mathrm{M} 1$ and $\mathrm{F} 1$ ) showed higher average values $(1.87 \mathrm{~m}$ and $1.73 \mathrm{~m}$ ) in this parameter than the rest of the sample, where this value decreases with performance. This is confirmed by the comparison between M1 and M3, which shows significant differences $(p=0.05)$.

Comparison of our results with the 91 winning male players at the FIVB beach volleyball tournaments ${ }^{7}$ shows a greater average height of $1.92 \mathrm{~m}$ as opposed to the $1.87 \mathrm{~m}$ of our top level sample (M1), clearly illustrating the disadvantage of our players in this parameter. The same occurs with the female players when we compare our sample with the 56 winning female players at the FIVB tournaments, ${ }^{6}$ whose average height was $1.78 \mathrm{~m}$ in comparison with the $1.73 \mathrm{~m}$ of our top ranking female players (F1). This pattern is confirmed in both male and female players on comparing our sample of top players ( $M 1$ and $F 1$ ) with earlier studies on elite players. ${ }^{4,5} \mathrm{~A}$ comparison of this study with players in the Brazilian men's beach volleyball series ${ }^{3}$ shows the lower height of our top male players (M1), with an average difference of $7 \mathrm{~cm}$. Our men's sample shows greater height, by just $2 \mathrm{~cm}$, when compared with 13 elite South African players. ${ }^{2}$

In terms of body weight, in the men's sample it was observed, with no significant differences, that the $M 1$ group weighs less, showing a pattern of lower ranking with increased body weight. However, this pattern was not seen in the female players, where results remained quite similar. A comparison of our results with a sample of top level international players ${ }^{4}$ shows lower values, with average differences of $12.07 \mathrm{~kg}$ for men and $2.01 \mathrm{~kg}$ for women. The average weight of elite male South African players ${ }^{2}$ is also lower, by $5.58 \mathrm{~kg}$. This pattern of lower weight in our top male players (M1) is confirmed by comparison of data obtained in other studies of elite players, ${ }^{3}$ with average differences of $14.87 \mathrm{~kg}$. These data indicate that our top male players are shorter and have less body weight than various elite players from a number of countries. These results may be conditioned by the lower age of our sample.

The increased body weight between $M 1$ and $M 3$ is primarily conditioned by the fat percentage $(8.4 \%$ versus $10.27 \% ; p=0.002)$ rather than the muscle tissue percentage, which maintains similar values in both groups. These increases in fat tissue between the top and the lower ranking players are confirmed by the weight in fat, with significant differences 




Figure 1. Box plots for muscle percentage, fat percentage and sum of skinfolds by ranking and gender.

between $M 1$ and $M 3$ ( $p=0.01)$. The sum of skinfolds also shows these significant differences between $M 1$ and $M 3$ ( $p=0.002$ ). Although our top ranking players are similar to lower ranking players in terms of muscle tissue, in both percentage and mass, they are differentiated by fat tissue (in both mass and percentage) and the sum of skinfolds.

The fat percentage data for $M 1$ in comparison with elite male Brazilian players ${ }^{5}$ show minimal average differences (0.3\%). In contrast, a comparison with the data for elite male South African players ${ }^{2}$ shows that the difference is favourable to our players, who have an average of $4.72 \%$ less fat.

For female players, body weight by ranking does not make any differences that need to be taken into account, showing no significant differences between weight and muscle percentage. However, differences are found when we compare groups $F 1$ and $F 3$ in fat percentage $(p=0.02)$ and sum of skinfolds $(p=0.02)$, with higher ranking players showing lower average values in these parameters (F1).

The somatotype of the male players in our study confirmed the pattern indicated above: increased weight is associated with differences in fat content. This is obvious when we observe the statistically significant differences in the endomorph component between groups $M 1$ and $M 3(p=0.001)$ and $M 1$ and $M 2(p=0.03)$. The mesomorphic component did not establish significant differences between our groups by ranking, confirming that muscle tissue does not differentiate the players in our sample. Ectomorphy, however, 
established significant differences between $M 1$ and $M 3(p=0.002)$ and between $M 1$ and $M 2$ ( $p=0.05)$, confirming once again that height is a particularly relevant component in differentiating the highest and lowest performing beach volleyball players.

In the female sample, it is worth noting the differences found between groups F1 and F3. Surprisingly, differences appear in the three components: endomorphy ( $p=0.007)$, mesomorphy $(p=0.03)$ and ectomorphy $(p=0.008)$, indicating that the difference between the highest and lowest performing female players in our study was determined by lower fat component and greater height.

\section{CONCLUSION}

The following conclusions can be made from the data obtained: a) Men's international elite players have a higher average age than our top male players (M1).

b) panish players of both genders are taller the higher their level is. However, the average height of our top male and female players (M1 and F1) is well below the average height of international elite players. c) The top Spanish beach volleyball players, both male and female, have lower body weight than elite players in this sport.

d) Height and fat component are responsible for differences between top beach volleyball players and others at lower levels, for both genders, and higher performing players are taller and have a lower fat component. e) The talent selection process in Spanish beach volleyball should aim to find taller individuals than the players it is currently choosing.

The data obtained allow us to outline the following considerations about the training process: a) the training process for beach volleyball players must be guided by the anthropometric profile of elite players, which is an essential factor in talent selection; and b) in each age category reference values for players' body composition need to be taken into consideration to enable them to reach higher levels of performance. It would be advisable for the Spanish beach volleyball competition calendar for all age categories to be annual rather than restricted to just three months, as a way to improve the structure of the training process for this sport. Future studies should be conducted in all age categories not studied so far to complete the anthropometric profile of beach volleyball players throughout their training process.

\section{ACKNOWLEDGEMENTS}

The authors are grateful to the Canary Islands Volleyball Federation for assistance in conducting this study during the Spanish Beach Volleyball Championships held in Gran Canaria in July 2011.

All authors declare no potential conflict of interest related to this article

AUTHORS' CONTRIBUTIONS: Each author made significant individual contributions to this manuscript. MEQE: writing, revision, data collection, statistical analysis, and analysis of the data; APM: data collection, statistical analysis, analysis of the data, writing and revision; SSM data collection and revision; DRR: statistical analysis; JMGM: intellection concept and preparation of the entire research project. All the authors reviewed and approved the final version of the manuscript

\section{REFERENCES}

1. Afonso GM, Marchi Junior W. Como pensar o Voleibol de Praia sociologicamente [How to think about beach volleyball sociologically]. Motriz. 2012;18(1):72-83.

2. Davies SE. Strength and power characteristics of elite South African beach volleyball players. J Res Sport Phys Educ Recreation. 2002;24(1):29-40.

3. Batista GR, Araújo RF, Guerra RO. Comparison between vertical jumps of high performance athletes on the Brazilian men's beach volleyball team. J Sport Med Phys Fitness. 2008;48(2):172-6.

4. Palao JM, Gutiérrez D, Frideres JE. Height, weight, body mass index, and age in beach volleyball players in relation to level and position. J Sport Med Phys Fitness. 2008;48(4):466-71.

5. Medeiros A, Mesquita I, Oliveira J, Loureiro AC, Afonso J, Monteiro LZ, et al. Body composition of Brazilian beach volleyball players. Br J Sports Med. 2010;44(14):i17

6. Giatsis G, Tili M, Zetou E. The height of the women's winners FIVB Beach Volleyball in relation to specialization and court dimensions. J Hum Sport Exerc. 2011;6(3):497-503.

7. Tili M, Giatsis $G$. The height of the men's winners FIVB Beach Volleyball in relation to specialization and court dimensions. J Hum Sport Exerc. 2011;6(3):504-10.

8. Fonseca CL, Fernandes RP, Fernandes-Filho J. Análisis del Perfil Antropométrico de Jugadores de la Selección Brasileña Infanto Juvenil. Int J Morphol. 2010;28(4):1035-41.

9. Martínez-Sanz JM, Pérez-Turpin JA, Sánchez-García LF, Urdampilleta A, Gómez-Zorita S, Cejuela-Anta R. Antropometría y composición corporal en jugadores de Voley-Playa del Campeonato Nacional Universitario de Alicante. Archivos de Medicina del Deporte. 2010a;139:412-13.

10. Martínez-Sanz JM, Pérez-Turpin JA, Cejuela-Anta R, Sánchez-García LF, Urdampilleta A. Composición corporal de jugadores de élite de Voley-Playa. Archivos de Medicina del Deporte. 2010b;139:414-15.
11. Martínez-Sanz JM, Cejuela R, Pérez-Turpin JA, Chinchilla JJ, Cortell-Tormo JM, Sánchez-García LF. Somatotipo en jugadores de élite de Voley-Playa. Archivos de Medicina del Deporte. 2010c;139:415.

12. Carter JE, Heath BH. Somatotyping: development and applications. Cambridge: Press Syndicate of the University of Cambridge, 1990

13. Lohman TG, Roche A, Martorell R. Anthropometric standardization reference manual. Champaign, IL: Human Kinetics, 1988

14. Garrow JS, Webster J. 1985. Quetelet's index (W/H2) as a measure of fatness. Int J Obes. 1985;9(2):147-53.

15. Carter JE. The Heath-Carter somatotype method. San Diego: San Diego State University, 1975.

16. De Rose EH, Guimaraes AC. A model for optimization of somatotype in young athletes. In: Ostyn M, Buenen G, Simons J (editors). Kinanthropometry II. Baltimore: University Park Press, 1980;77-80.

17. Matiegka J. The testing of physical efficiency. Am J Phys Anthrop. 1921;4(3):223-30.

18. Carter JE. Body composition of Montreal Olympic Athletes. In: Carter JE (editor). Physical Structure of Olympic Athletes. Part I. Montreal Olympic Games Anthropological Project. Basel: Karger, 1982;107-16.

19. Durnin JV, Rahaman MM. The assessment of the amount of fat in the human body from measurements of skinfold thickness. Br J Nutr. 1967;21(3):681-9.

20. Martorell R, Mendoza F, Mueller WH, Pawson YG. Which side to measure: right or left? In: Lohman TG Roche AF, Martorell R (editors). Anthropometric standardization reference manual. Champaign IL: Human Kinetics, 1988;87-92

21. Housh TJ, Johnson GO, Housh DJ, Kenney KB, Hughes RA, Thorland WG, et al. The effects of age and body weight on anthropometric estimations of minimal wrestling weight in high school wrestlers. Res $Q$ Exerc Sport. 1990;61(4):375-82 